\title{
The Clinical Significance and Age Analysis of Patients Admitted to the Emergency Department with Chest Diseases
}

\author{
다 Fatma Tokgöz Akyıl, ${ }^{1}$ ㄴ Sinan Yıldırım²
}

\author{
'Department of Chest Diseases, \\ Çanakkale Mehmet Akif Ersoy State \\ Hospital, Çanakkale, Turkey \\ 2Department of Emergency Medicine, \\ Çanakkale Mehmet Akif Ersoy State \\ Hospital, Çanakkale, Turkey \\ Submitted: 14.01.2019 \\ Accepted: 08.04.2019 \\ Correspondence: Fatma Tokgöz Akyıl, \\ Çanakkale Devlet Hastanesi, Göğüs \\ Hastalıkları Kliniği, Çanakkale, Turkey \\ E-mail: fatmatokgoz86@gmail.com
}

aryar

Keywords: Bronchitis, chest diseases, chronic obstructive pulmonary disease; emergency department.

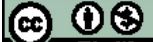

This work is licensed under a Creative Commons Attribution-NonCommercial 4.0 International License.

\begin{abstract}
Objective: The elderly population is on an increasing trend around the world and constitutes around every one of five admissions in the emergency department (ED). The present study aims to analyse patients according to age who were admitted to ED for chest disease.

Methods: This study was a retrospective and observational study conducted in a state hospital. All adult ED admissions with a pulmonary disease were investigated. Patients were divided into two groups according to their ages as $<65$ and $\geq 65$. The diagnoses and treatment results were analyzed.
\end{abstract}

Results: Pulmonary patients constituted $6.5 \%$ of all admissions. Patients with bronchitis were the youngest, while respiratory failure patients were the oldest. The hospitalization rate was $35 \%$ and in $29 \%$ a pulmonologist consultation was carried out. In this study, $45 \%$ of the admissions were aged $\geq 65$. Elderly patients were more frequently consulted to a pulmonologist $(p<0.00 \mathrm{I})$ and hospitalized $(\mathrm{p}<0.00 \mathrm{I})$ with a longer hospitalization duration $(p=0.048)$. The group of the elderly patients also demonstrated higher hospital mortality rates $(p<0.001)$.

Conclusion: Pulmonary patients constitute a significant part of ED admissions and the elderly patient population within this population is dense. Elderly patients require more frequent hospitalization and specialist consultation. They require longer treatment duration and have higher mortality rates. All professionals/staff trained and work in the pulmonary health area bear an important level of responsibility for the care of elderly patients.

\section{INTRODUCTION}

Emergency department is among the most demanding of frequent specialist consultations for both diagnostic and therapeutic approaches. They are also important hospital units providing continuous care. ${ }^{[1,2]}$

The elderly population is increasing all over the world. In Japan, the country with the longest life expectancy, the population aged over 65 years, defined as elderly, is over $23 \%$ of overall population..$^{[3]}$ This rate is over $20 \%$ in Europe, and it is expected to be around $50 \%$ in $2050 .{ }^{[4]}$ In our country, Turkey, the elderly populationhas increased over the years and was recorded as $8.3 \%$ in $2016 .^{[5]}$

Significant changes occur with age, even in healthy lungs. Lung volume and reserve are reduced, accessory respiratory muscles weaken, particles cannot be cleaned adequately because cough capacity decreases, and the defense mechanisms of the lung are disrupted..$^{[6]}$ In addition, chronic obstructive pulmonary disease, lung fibrosis and pneumonia show a significant increase with age..$^{[7]}$
Elderly patients constitute an important part of the ED admissions and these patients commonly need hospitalization. According to research carried out both in the world and in our country, patients aged 65 and above constitute $10-25 \%$ of the overall emergency service admissions. It has been determined that patients with chest diseases have a significant importance, especially among elderly patients hospitalized in the wards of internal diseases. ${ }^{[8-11]}$ However, only limited data categorized according to their age groups are available on patients with chest diseases.

The aim of the present study is to analyse patients admitted to ED with chest diseases according to age groups.

\section{MATERIALS AND METHODS}

The present study is a retrospective, observational study conducted in a secondary care state hospital. One university and one state hospital are localized in the province where this study was conducted. The city's tourism centers, which cause population growth in summer, are 
far from the city center and there are two district state hospitals closer to the tourist attraction sites.

In this study, adult ED admission records entered between September 2017 and September 2018 were screened from the hospital automation system. Among these admissions, admissions associated with chest diseases were evaluated.

Diagnoses related to chest diseases were coded according to ICD-I0 (International Classification of Diseases-10th version) as follows: A 15, A 16, A 19, B90 (respiratory tract tuberculosis, miliary tuberculosis): C34, R9I (malignant neoplasm of bronchi or lung); J10-J99: (respiratory system diseases, except acute upper respiratory tract infections); $126,127,128$, 182 (pulmonary embolism and pulmonary vascular diseases); R04 (bleeding arising from the respiratory tract); R05 (cough); R06 (respiratory abnormalities).

Diseases were investigated in 14 subgroups as follows: bronchitis (acute/chronic), chronic obstructive pulmonary disease (COPD), pneumonia, dyspnea, asthma, lung cancer, pulmonary embolism, respiratory failure, pleural diseases, hemoptysis, tuberculosis, bronchiectasis, interstitial lung disease and other (cough, other pulmonary diseases).

Distribution of the admissions according to months and hours, patients' demographics, and frequency of chest diseases consultations, treatment results and in-hospital mortalities were recorded. All patients were divided into two groups as $<65$ and $\geq 65$ years and diagnosis and treatment results were compared between the groups. Ethics committee approval was received for this study from Canakkale Onsekiz Mart University Ethic Committee (02.01.2019, No: 20I I-KAEK-27 / 2018-1800 1838I8).

\section{Statistical analysis}

The data were recorded into SPSS (statistical package for social sciences for Windows, version 16.0; SPSS Inc.; Chicago, IL, USA). Continuous variables with normal distribution were expressed as mean \pm standard deviation, while variables with non-normal distribution as median (minimum-maximum). Categorical variables were expressed in numbers and percentages. As for continuous variables, the significance of the difference between the means of the group was determined using the Mann-Whitney $U$ test for groups with non-normal and Student's t-test for normal distribution. Pearson chi-square and, where appropriate, Fisher Exact Test were used to test the significance of the difference between categorical variables. $P$-values of $<0.05$ were considered statistically significant.

\section{RESULTS}

Only 3703 (6.5\%) of a total of 56.958 ED admissions were associated with chest diseases. While $40 \%(n=1487)$ of the patients were female and $45 \%$ of the cases were $\geq 65$ years (mean age $59 \pm 20$ (17-100 years)). The admissions to ED were most frequent in March and February, and least frequent in November and June. The admissions were mostly made between 12:00-16:00 PM, and rarely between 04:00-

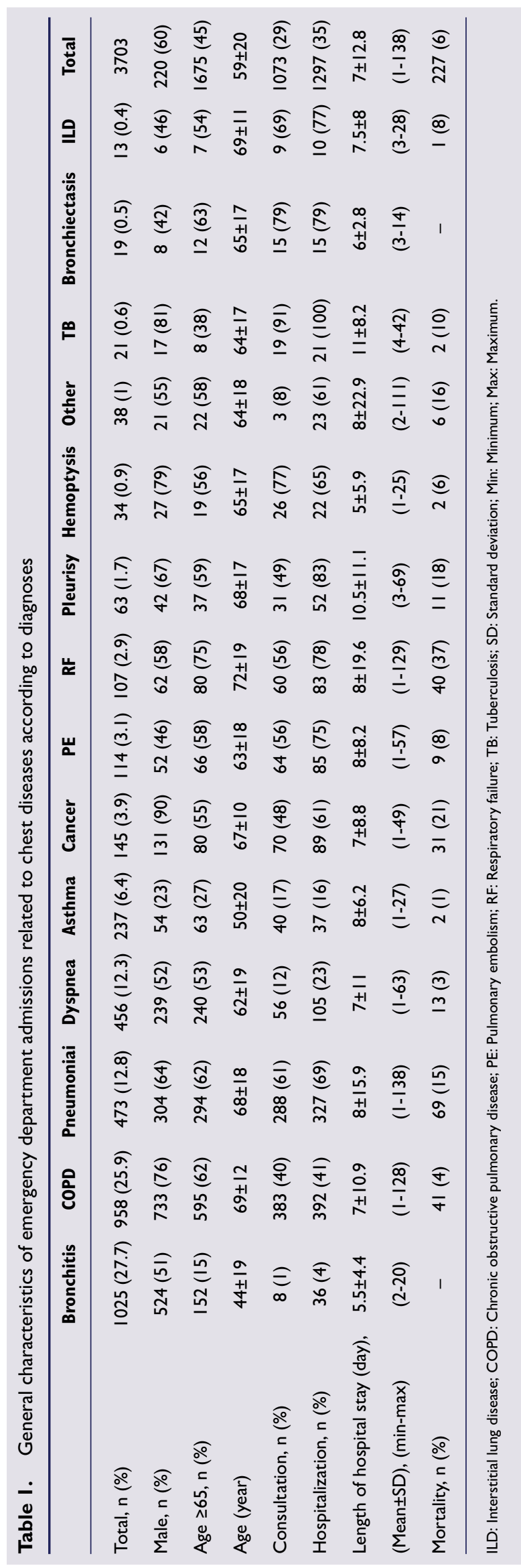


08:00 AM. The most common diagnoses were bronchitis and COPD (27.7\% and $25.9 \%$, respectively).

When the mean age of the patients was evaluated according to the diagnoses, patients with bronchitis $(44 \pm 19)$ and asthma $(50 \pm 20)$ constituted the youngest, and patients with respiratory failure $(72 \pm 19)$ comprised the oldest group. Female gender was predominant in patients with bronchiectasis, pulmonary embolism, and asthma, while a comparable number of female and male patients had bronchitis (Table I).

Patients applied to emergency departments were discharged with outpatient treatment (64\%), hospitalized $(35 \%)$, or referred to another center $(2 \%)$. The most common diagnoses that required referrals were COPD $(n=23)$, dyspnea $(n=16)$ and pneumonia $(n=11)$. Patients with bronchitis and asthma were rare, while the patients with tuberculosis were most frequently hospitalized. The median duration of hospitalization was $7 \pm 12.8$ (I-138) days. Patients with tuberculosis and pleural diseases needed the longest hospitalizations, while the patients with hemoptysis and bronchitis needed the shortest hospitalizations (Table I). During hospitalization, 227 patients (6\%) died.

In $1073(29 \%)$ of the admissions, the expert opinion of a specialist was taken. Consultations were requested most frequently in December and most rarely in August (33\%, and $25 \%$ respectively). Consultation rates were the highest between 12:00 PM-04:00 AM and the lowest between

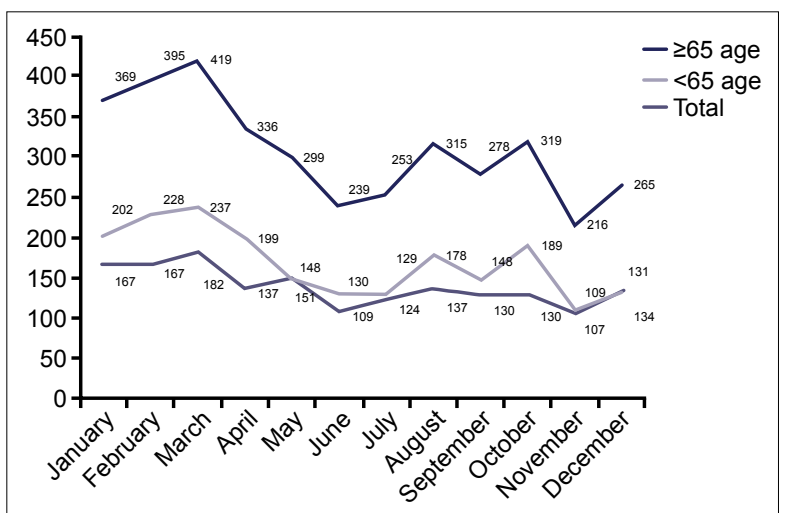

Figure 1. Distribution of months of applications of the patients according to age groups.

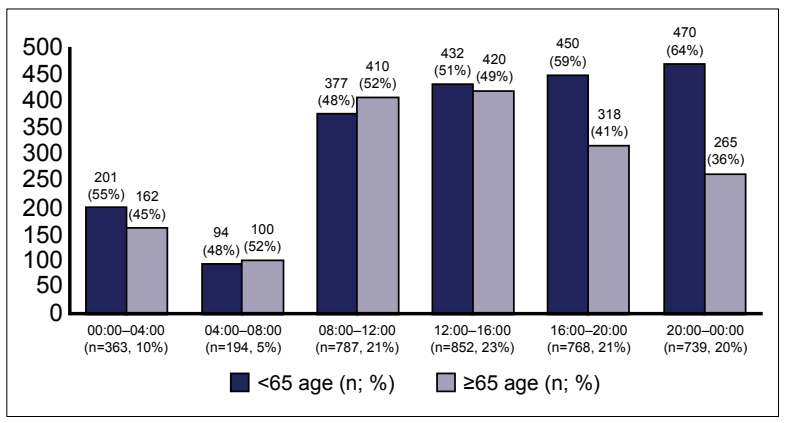

Figure 2. Distribution of hours of applications of the patients according to age groups.

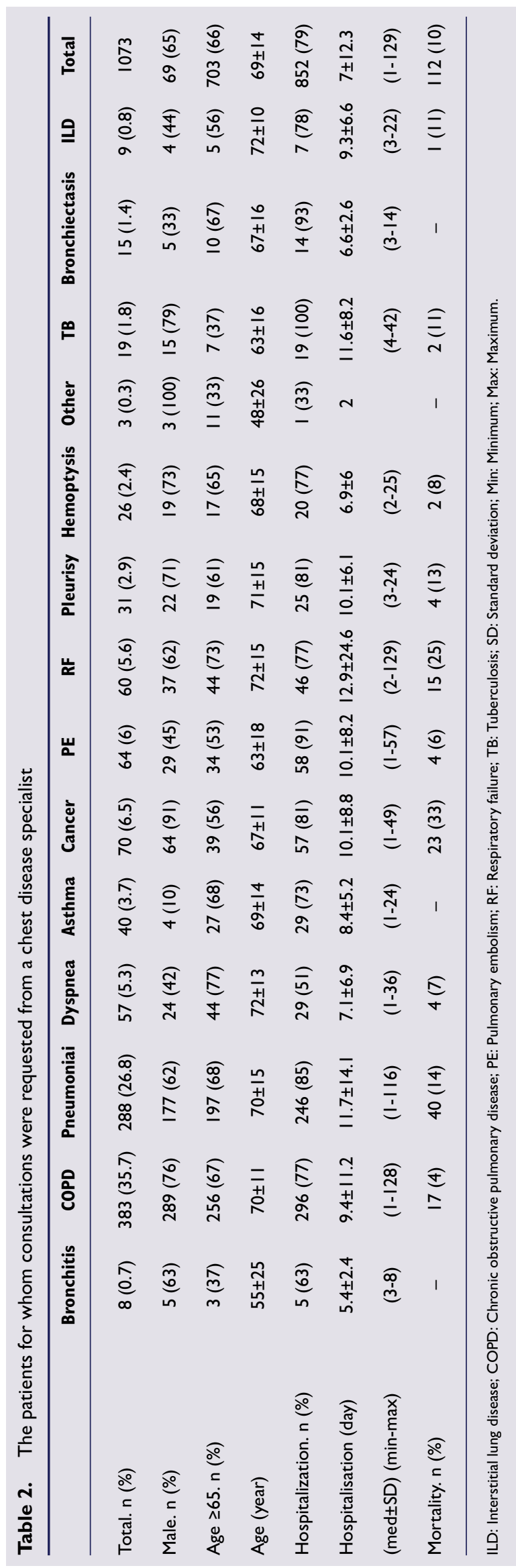


Table 3. Comparison of the patients' characteristics and outcomes according to age groups

\begin{tabular}{|c|c|c|c|}
\hline & $\begin{array}{c}<65 \\
(n=2028, \\
55 \%)\end{array}$ & $\begin{array}{c}\geq 65 \\
(n=1675, \\
45 \%)\end{array}$ & $\mathbf{p}$ \\
\hline Female/male & $\begin{array}{c}815 / 1213 \\
(40 / 60)\end{array}$ & $\begin{array}{c}668 / 1007 \\
(40 / 60)\end{array}$ & 0.886 \\
\hline $\begin{array}{l}\text { Presentation between } \\
08: 00-16: 00\end{array}$ & $809(40)$ & $830(5 \mathrm{I})$ & $<0.001$ \\
\hline Consultation & $370(18)$ & $703(42)$ & $<0.001$ \\
\hline Hospitalization & $44 I(22)$ & $856(5 \mathrm{I})$ & $<0.001$ \\
\hline Length of hospital stay (days) & $10.0 \pm 11.3$ & $11.8 \pm 13.5$ & 0.048 \\
\hline In-hospital mortality & $47(2)$ & $180(11)$ & $<0.001$ \\
\hline
\end{tabular}

8:00 AM-00:00 AM (36\%, and 18\%, respectively) (Figures I and 2). Expert opinions were most frequently requested for patients with tuberculosis, hemoptysis and pneumonia, and most rarely for patients with bronchitis. Forty (4\%) of them were referred to another center, and $79 \%(n=852)$ of them were hospitalized. Most frequent referral indications to another center were COPD $(n=15)$, pneumonia $(n=8)$ and respiratory failure $(n=6)$. Hospital mortality was $10 \%$ among the consultation requested patients. The highest mortality rates were observed in patient groups with lung cancer $(33 \%)$ and respiratory failure $(25 \%)$ (Table 2 ).

When the patients were evaluated according to age, the frequency of presentation to emergency departments by gender and months of admission was similar between the two groups ( $p>0.05$ ) (Fig. I). Younger ( $<65$ years) and elderly (>65 years) patients most frequently applied to the emergency services between 8:00 and 00:00 and 8:00 and 12:00 hours, respectively (Fig. 2). The patients under the age of 65 had lower admission rates during working hours (08:00-16:00) when compared with younger patients $(40 \%$ and $51 \%, \mathrm{p}<0.00 \mathrm{I}$, respectively).

Chest consultations were more frequently requested for elderly patients relative to younger patients $(42 \%$ and $18 \%$, respectively, $\mathrm{p}<0.00 \mathrm{I})$. A significantly higher number of elderly patients $(5 \mathrm{l} \%)$ required hospitalization when compared to younger patients $(22 \%)(p<0.001)$. The duration of hospitalization was longer in elderly patients ( $11.8 \pm 13.5$ vs $10.0 \pm 11.3$ days, $p=0.048$, respectively). Hospital mortality was observed in $11 \%$ of the elderly and in $2 \%$ of the patients under 65 years of age $(p<0.001)$ (Table 3$)$.

\section{DISCUSSION}

In our study in which adult emergency admissions were evaluated in detail concerning chest diseases, a significant proportion of all ED admissions with symptoms of chest diseases, required a chest disease specialist consultation. Approximately half of these patients requiring consultation from a specialist, were 65 years or older, hospitalized more frequently, and had higher rates of in-patient mortality. These results reveal the higher impacts of patients with chest diseases. The findings of the present study emphasize the importance of the burden imposed on all professionals dealing with chest diseases.

In our country, the elderly population is increasing in parallel with the world. The elderly population in our country increased from $7.5 \%$ in 2012 to $8.3 \%$ in 2016 . The life expectancy is 78 years on average. ${ }^{[5]}$ Therefore, self-care and home care of elderly patients, monitoring of existing diseases and comorbid conditions will become increasingly important concerning health policies. It has been detected that $7-23 \%$ of the ED admissions consisted of elderly patients. ${ }^{[9,11,12]}$ It has been reported that emergency service admissions in Van province recorded within one month consisted of patients aged over 65 years. ${ }^{[12]}$ Kilinc et al. ${ }^{[13]}$ reported that $15 \%$ of all admissions to ED of a state hospital within one year were elderly patients, while $17 \%$ of them had respiratory complaints and $19 \%$ of them were hospitalized in Chest Diseases Clinic. A multicenter study in the United States found that $22 \%$ of ED admissions consisted of elderly patients. ${ }^{[8]}$ While the rate of the population aged 65 and over is $8.3 \%$ in our country, this rate is $14 \%$ in the province of Çanakkale, where the study was carried out. ${ }^{[14,15]}$ In our series, elderly patients constituted approximately half of all chest disease patients. This admission rate is higher when compared with all ED admittance data and shows that the incidence rate of chest diseases significantly increased among elderly patients. However, it has been thought that new multicentre studies on this subject may shed light on the importance of elderly population density among chest patients.

Avcl et al. ${ }^{[10]}$ reported that $53 \%$ of the patients aged 65 years and older admitted to the ED were male and $65 \%$ of them required inpatient treatment. It has been determined that patients were most frequently hospitalized in the clinics of internal medicine and chest diseases, whereas males were more often hospitalized than females. In another study, male gender dominated among elderly chest disease patients. ${ }^{[1]]}$ Similarly, in our study, the male gender was dominant in all age groups and no gender difference was observed between ages.

In a study from the US, the top-five non-traumatic diagnoses listed were pneumonia, congestive heart failure, nonspecific chest pain, septicemia, COPD and bronchiectasis, respectively. ${ }^{[16]}$ In national studies, it has been reported that among all cancers, lung cancer was the most frequent ED admission reason and multiple lung metastases were the most common non-pulmonary metastatic malignancies. ${ }^{[17,18]}$ In our series, bronchitis was the most common diagnosis among chest disease patients, while hospitalization was required in $4 \%$ of them and consultation from a chest disease specialist was required in lower than $1 \%$. Besides, it was thought that some patients misused the emergency services. In Italy, COPD accounts for $0.5 \%$ of all emergency admissions, which corresponds to $0.2 \%$ of all patients in our series. ${ }^{[19]}$ Pneumonia was the third most common non-traumatic diagnosis in the USA. 
Pneumonia conveys importance in that it is among the first top five indications for admission. Besides, pneumonia patients have the highest inpatient mortality rates, and most frequently require consultation and hospitalization. In our series, cancer patients ranked sixth among all pulmonary diseases patients and one out of every five patients was died.

Consultation means that the physician responsible for the patient is guided by the patient's follow-up by taking the opinion of the other physician or physicians during followup. In our country, consultation rates in ED are between 20-40\%. ${ }^{[1,20,21]}$ Cardiology, internal diseases, chest diseases and neurology are the most frequent consultation requested departments. ${ }^{[21]}$ Aydın et al. ${ }^{[22]}$ reported that most frequently admissions to ED of a university hospital occurred between 12.00-16.00 hours in all age groups within three months, and that chest consultation was requested in7.3\%. ${ }^{[22]}$ Similarly, in our study, the peak hours in all age groups were between 12.00-16.00 hours. Patients under 65 years of age applied to the hospital more frequently between 20:00-00:00 hours because only on those hours they might have found spare time to seek for healthcare.

In present study, the frequency of chest disease consultation was not investigated concerning all emergency admissions, and $29 \%$ of the chest disease patients were asked for their opinions.

Discharge rates from ED are reported as $81-88 \%$ in our country. ${ }^{[17,21-23]}$ Kekeç et al. reported that $60 \%$ of the patients aged $\geq 65$ years applying to ED of a university hospital in Adana, were hospitalized, and $5.1 \%$ of them werehospitalized in the chest diseases clinic. ${ }^{[16]}$ In another study investigating elderly patients, $20 \%$ of the hospitalizations of ED admissions, were most frequently to the clinics of cardiology and chest diseases among clinics of internal diseases. ${ }^{\left[{ }^{9]}\right.}$ In the Netherlands, $74 \%$ of all patients aged $\geq 65$ years were hospitalized. ${ }^{[24]}$ In our study, all chest disease patients had higher hospitalization rates, while elderly patients had lower ones. We believe that further multicentre studies are needed to investigate the causes and consequences of treatment applications regarding the chest disease patients.

In the study of Avcl et al., mortality was observed in $11.6 \%$ of all patients aged 65 years or older who had been admitted to the ED. ${ }^{[10]}$ Brouns et al. reported a relevant mortality rate as $9.5 \% .{ }^{[24]}$ In line with the literature, the present study manifested II\% of mortality in the elderly.

The most important limitation of our study is that it was a retrospective and single center study. The second limitation is that all ED admissions could not be compared but only admittance with chest diseases were screened. On the other hand, our hospital has the highest bed capacity of the city and to the best of our knowledge, the clinical importanceof chest diseases patients among ED admissions has been evaluated thoroughly for the first time.

In conclusion, patients with chest diseases have a significant clinical importance among ED admissions. Approximately half of these patients are older than 65 years. Elderly patients more frequently require hospitalization, longer hospital stay and they have higher in-hospital mortality. Considering the physiological consequences of the increasing elderly population rate and the aging lungs, both in our country and in the world, an important responsibility falls on all health-care team serving in chest diseases field.

Ethics Committee Approval

Approved by the local ethics committee.

Informed Consent

Retrospective study.

Peer-review

Internally peer-reviewed.

Authorship Contributions

Concept: F.T.A., S.Y.; Design: F.T.A., S.Y.; Supervision: F.T.A., S.Y.; Fundings: F.T.A., S.Y.; Materials: F.T.A., S.Y.; Data: F.T.A., S.Y.; Analysis: F.T.A.; Literature search: F.T.A.; Writing: F.T.A.; Critical revision: F.T.A., S.Y.

Conflict of Interest

None declared.

\section{REFERENCES}

1. Woods RA, Lee R, Ospina MB, Blitz S, Lari H, Bullard MJ, et al. Consultationoutcomes in theemergencydepartment: exploringratesandcomplexity. CJEM 2008;10:25-31. [CrossRef]

2. Siegler M. Training doctors for professionalism: some lessons from teaching clinical medical ethics. Mt Sinai J Med 2002;69:404-9.

3. Meiners S, Eickelberg O, Königshoff M. Hallmarks of theageinglung. EurRespir J 2015;45:807-27. [CrossRef]

4. http://www.silvereco.org/en/statistics/Accessed Dec 12, 2018.

5. http://www.tuik.gov.tr/PreHaberBultenleri.do?id=24638

6. EM, Brubaker AL, Kuhlmann E, Kovacs EJ. Theaginglung. ClinIntervAging 2013;8:1489-96. [CrossRef]

7. Bowdish DME. The Aging Lung: Is Lung Health Good Healthfor Older Adults? Chest 2019;155:391-400. [CrossRef]

8. Venkatesh AK, Dai Y, Ross JS, Schuur JD, Capp R, Krumholz HM. Variation in US Hospital Emergency Department Admission Ratesby Clinical Condition. MedCare 2015;53:237-44. [CrossRef]

9. Şahin S, Boydak B, Savaş S, Akif Yalçın M, Akçiçek F. Acil Servise Başvuran 65 Yaş ve Üzeri Hastaların Özellikleri. AKAD Geriatri 2011;3:41-6.

10. Avc1 S, Erdogdu Hİ. Evaluation of Geriatric Patients Admitted to Emergency Service According to Gender. Kafkas J MedSci 2017;7:209-13. [CrossRef]

11. Gülalp B, Aldinç H, Karagün Ö, Çetinel Y, Benli S. The Complaintand Outcome of Geriatric Patients in Emergency Department. Turk J EmergMed 2009;9:73-7.

12. Köse A, Köse B, Öncü MR, Tuğrul F. Admission appropriateness and profile of the patients attended to a state hospital emergency department. Gaziantep Med J 2011;17:57-62. [CrossRef]

13. Kılınç AS, Çatak B, Badıllığlu O, Sütlü S, Dikme Ö, Aydın A, et al. Causes and consequences of the admission to the emergency department in elderly. [Article in Turkish]. SDÜ Tip Fak Derg 2012;19:139-43.

14. Türkiye İstatistik Kurumu, İstatistiklerle Yaşlilar 2016, Sayı:24644.

15. Kara T, Atasoy E. Canakkale Province From An Educational Perspective. Atasobed 2018;22:1233-57 
16. Kekeç Z, Koç F, Büyük S. Review of Geriatric Patients Hospitalization in Emergency Department. JAEM 2009;8:21-4.

17. Tanriverdi O, Beydilli H, Yildirim B, Karagoz U. Single Center Experience on Causes of Cancer Patients Visiting the Emergency Department in Southwest Turkey. Asian Pac J Cancer Prev 2014;15:68790. [CrossRef]

18. Sadik M, Ozlem K, Huseyin M, AliAyberk B, Ahmet S, Ozgur O. Attributes of cancer patients admitted to the emergency department in one year. World J Emerg Med 2014;5:85-90. [CrossRef]

19. Germini F, Veronese G, Marcucci M, Coen D, Ardemagni D, Montano $\mathrm{N}$, et al. COPD exacerbations in the emergency department: Epidemiology and related costs. A retrospective cohort multicentre study from the Italian Society of EmergencyMedicine (SIMEU). Eur J Intern Med 2018;51:74-9. [CrossRef]

20. Karakaya Z, Gökel Y, Açkalın A, Karakaya O. Evaluation of the process and effectiveness of consultation system in the Department of
Emergency Medicine. Ulus Travma Acil Cerrahi Derg 2009;15:210_ 6.

21. Ergin M. Acil servis kalabalığının bilimsel yöntemler ile ölçümü. Uzmanlık tezi, Ankara: Gazi Üniversitesi Tip Fakültesi, Acil Tip Anabilim Dal, 2008.

22. Aydın T, Aydın ŞA, Köksal O, Özdemir F, Kulaç S, Bulut M. Evaluation of Features of Patients Attending the Emergency Department of Uludag University Medicine FacultyHospital and Emergency Department Practices. JAEM 2010;9:163-8. [CrossRef]

23. Kılıçaslan İ, Bozan H, Oktay C, Göksu E. Demographic properties of patients presenting to the emergency department in Turkey. Turk J Emerg Med 2005;5:5-13.

24. Brouns SHA, Wachelder JC, Jonkers FS, Şambooij SL, Dieleman JP, Haak HR. Outcome of elderly emergency department patients hospitalised on weekends -a retrospective cohort study. BMC Emergency Medicine 2018;18:9. [CrossRef]

\section{Acil Serviste Göğüs Hastalarının Önemi ve Yaşa Göre Analizi}

Amaç: Tüm dünyada yaşlı nüfus giderek artmakta ve beklenen yaşam süresi uzamakta olup yaşlı hastalar acil başvurularının yaklaşık beşte birini oluşturur. Çalışmanın amacı, acil servise başvuran göğüs hastalarının yaş gruplarına göre analiz etmektir.

Gereç ve Yöntem: Çalışma, bir devlet hastanesinde gerçekleşen, geriye dönük gözlemsel bir çalışmadır. Eylül 20।7-Eylül 20।8 arasındaki erişkin acil servis başvurularından göğüs hastalıkları ile ilişkili tanı konulanlar incelendi. Hastalar $<65$ ve $\geq 65$ yaş olmak üzere iki gruba ayrılarak tanı ve tedavi sonuçları karşılaştıııldı.

Bulgular: Tüm acil servis başvurularının \%6.5'ini göğüs hastaları oluşturmuştu. Başvurular en sık Mart ayında ve en yoğun 12:00-16:00 arasındaydı. En genç grubu bronşit, en yaşı hastaları ise solunum yetersizliği hastaları oluşturdu. Hastaların \%35'i hastaneye yatırılmış ve \%29'unda göğüs uzmanı konsültasyonu yapılmıştı. Hastaların \%45'i 65 yaş ve üstündeydi. Yaşlı hastalarda göğüs konsültasyonu sıklığı daha yüksek, hastane yatışları daha sık $(p<0.00 I)$, yatış süresi daha uzun $(p=0.048)$ ve hastane mortalitesi daha yüksek $(p<0.00 \mathrm{I})$ saptandı.

Sonuç: Göğüs hastaları acil servislerde önemli bir yer tutar ve yaşlı hasta popülasyonu yoğundur. Yaşlı hastalarda daha sık uzman görüşü ve hastane yatışı, daha uzun hastane tedavisi gerekmekte ve daha yüksek mortalite oranları izlenmektedir. Göğüs hastalıkları alanında eğitim alan ve çalışmakta olan tüm personelin üzerine yaşlı hastaların izlemi açısından önemli bir sorumluluk düşmektedir.

Anahtar Sözcükler: Acil servis; bronşit; göğüs hastalıkları; KOAH. 